\title{
Heterogenous Banks and Macroprudential \\ Regulations
}

by

Subhendu Bhowal

B. Tech, M.Tech, IIT Kharagpur (2008)

P.G.P.M, IIM Ahmedabad (2010)

Submitted to the Sloan School of Management

in partial fulfillment of the requirements for the degree of

MASTER OF SCIENCE IN MANAGEMENT RESEARCH

at the

\section{MASSACHUSETTS INSTITUTE OF TECHNOLOGY}

February 2019

(C) Massachusetts Institute of Technology 2019. All rights reserved.

Author..........

\section{Signature redacted}

\section{Signature redacted $\quad$ February 11, 2019}

Certified by ...

Accepted by...

\section{Signature redacted}

Adrien Verdelhan Associate Professor

Thesis Supervisor

Ezra Zuckerman Sivan

Alvin J. Siteman (1948) Professor of Entrepreneurship and Strategy

Deputy Dean

Professor, Technological Innovation, Entrepreneurship, and Strategic

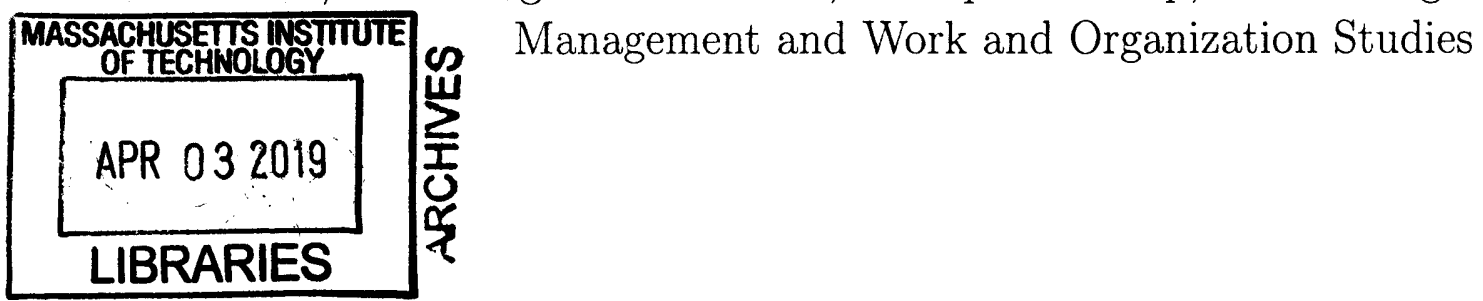


. 


\title{
Heterogenous Banks and Macroprudential Regulations
}

\author{
by \\ Subhendu Bhowal \\ Submitted to the Sloan School of Management \\ on February 11, 2019, in partial fulfillment of the \\ requirements for the degree of \\ MASTER OF SCIENCE IN MANAGEMENT RESEARCH
}

\begin{abstract}
This paper studies how financial intermediation varies across banks. Bank size is a first-order determinant of banks' capital structure in the cross-section. Largest banks have the lowest capital-to-asset ratio and the lowest ratio of Tier-1 capital against risk-weighted assets. These large banks earn a larger interest income per dollar invested in their loan portfolio than small banks, and they maintain the highest net interest margins among all banks. A cash flow sensitivity analysis shows that the largest banks are the most tightly constrained by minimum capital requirement, while all other banks maintain capital in excess of minimum capital requirement regulation. Empirically, banks do not adjust their lending portfolio dollar for dollar as their net profits increase or lever up immediately by issuing more deposits. Further, we find that the financial accelerator amplifies productivity shock in aggregate data. The impulse response to total productivity shock shows that the loan volume of the capital-constrained largest banks does not respond positively to positive productivity shocks. This is in contrast to smaller banks that increase loans when productivity improves in the economy.
\end{abstract}

Thesis Supervisor: Adrien Verdelhan

Title: Associate Professor 



\section{Acknowledgments}

Firstly, I would like to express my gratitude to Adrien Verdelhan for his continuous support during the toughest times. I am indebted to him for his kindness, patience and generosity.

I would like to express my deepest appreciation to Jason McKnight, Assistant Dean for Graduate Education, who provided me the possibility to complete this report. I'd like to thank Larry Anderson and Dawn Anderson, and Michael Collins for making my life easier in Tang Hall of Residence.

I have a great fortune to receive unwavering support from family and friends that made the journey easier. Sourav Sarkar and Giulio Alighieri have been dear friends during my time at MIT. I cherish the countless hours I have spent with these two people. I had several interesting discussions with Fernando Martins, Maarten Meeuwis, Leonardo Elias and Fangzhou Lu over the years.

I'm especially grateful to my mother Sipra Bhowal for everything in my life. Deepest gratitude to my girlfriend Srabonti Chakraborty, for all her love and support.

Finally, nothing would have been possible without my father Late Sukhendu Bikash Bhowal. I miss you, dad! 


\section{Contents}

1 Introduction . . . . . . . . . . . . . . . . . 12

2 Literature Review . . . . . . . . . . . . . . . . . 15

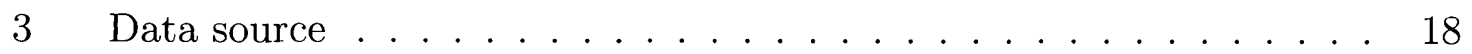

4 Bank Characteristics and Summary Statistics . . . . . . . . . . . 19

5 Investment Cash Flow Sensitivity of Banks . . . . . . . . . . . . 25

6 Estimating Impulse Response in the Data . . . . . . . . . . . . . . . 32

6.1 IRF in Aggregate Time Series Data . . . . . . . . . . . 33

6.2 IRF in the Panel Data for US Banking . . . . . . . . . . . . 40

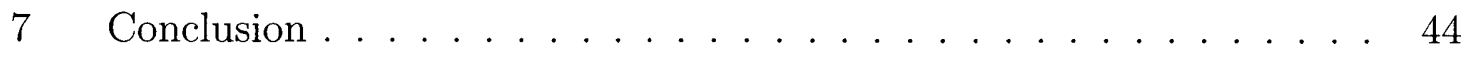




\section{List of Figures}

1 Average Equity to Asset Ratio by Size Decile . . . . . . . . . . . . 21

2 Average Leverage, Interest Income, Interest Expense and NIM by Size Decile . . . . . . . . . . . . . . . . . . . . 22

3 Average Loan to Asset, Tier-1 Capital to Risk Weighted Asset, Average Deposit to Asset and Average Non-Deposit Liabilities to A byt Size Decile . . . . . . . . . . . . . . . . . . . . . . . . . . . . . 24

4 Effects of TFP shock, Jorda local projection, on real variables . . . 37

$5 \quad$ Effects of TFP shock, Jorda local projection, on price cost margin . . 38

6 Effects of TFP shock, Jorda local projection, on total loans, interest income, interest expense and average NIM . . . . . . . . . . 42 


\section{List of Tables}

1 Summary Statistics for All Banks in the entire Panel Data (1983Q1

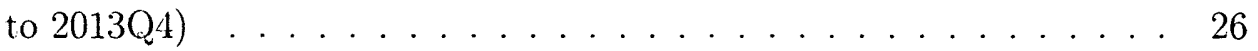

2 Summary Statistics for Banks in Highest Decile and Highest Percentile in the entire Panel Data (1983Q1 to 2013Q4) . . . . . . . . . . . 27

3 Cash Flow Sensitivity of Bank Loans and Deposits Controlling for $10-$ Year Bond Spread . . . . . . . . . . . . . . . . . . 34

4 Cash Flow Sensitivity of Bank Loans and Deposits Controlling for NIM 35 


\section{Introduction}

The size of financial intermediaries affects the capital structure decisions. The funding cost and the average interest income vary systemically across size deciles. Banks in the highest size deciles are considered systemically important and often considered too-big-to-fail. Since financial crisis, the systemically important banks have received both more stringent regulatory scrutiny and inordinate amount of Government support to avoid failure. As macroeconomic modeling incorporate financial frictions, this differential effects of size has been largely ignored by equilibrium models with financial frictions. This raises the question: How does size affect financial intermediation in data?

The objective of this paper is to examine whether there bank size is a first order determinant of banks capital structure in the cross-section. I examine whether banks are truly constrained by capital requirements. I further investigate how productivity shock propagates differently across different sizes of bank.

I find that several bank capital structure variables show clear relationship with sizes. Average equity to asset is declining in size and alternatively, average book leverage ratio is increasing in size. The average interest income and average net interest margin for the highest decile is sharply higher than the other banks. Also average loan to asset ratio, average non-deposit liabilities increase with size. Tier-1 capital to risk weighted asset falls with size.

I estimate cash flow sensitivity for the banks along the strategy Fazzari et al. (1988). I show that the regression coefficients of contemporaneous loan and next quarter loan net profit is increasing in size and lines up perfectly. I find that the same monotonicity in the coefficients for deposit on net profit is not obtained. The results show that banks are constrained by capital, however, the tightness increases with 
size. Also, as bank net worth improves, the banks do not adjust lending immediately dollar for dollar, or cannot increase deposit taking to the tune of leverage ratios.

Finally, using Jordà (2005) projection technique to confirm financial accelerator in aggregate data. However while applying the same technique to the panel data for US banking system. I find that for the largest decile of banks, loan volume do not go above equilibrium level on positive TFP shock. However all other banks see loan growth when productivity improves in the economy. Finally, the NIM for large banks never see any positive jump on productivity rise and stays below normal.

Global financial crisis of 2007-2012 prompted regulatory bodies to protect the global financial system through preventing the failure of systemically important financial institutions (SIFI), or, if one does fail, limiting the adverse effects of its failure. Basel III regulations specifically target the large banks and place a higher bank capital requirements and capital surcharges for systemically important banks. While the large banks are constrained by more stringent regulatory requirements, they have historically received support from the government to avoid failure. Thus depositors perceive these banks as safe and the SIFIs can issue deposits at a lower cost unlike banks in other size deciles (Acharya and Mora (2012), Acharya et al. (2010)).

The seminal papers by Bernanke et al. (1994), Bernanke et al. (1999) introduced financial frictions in credit markets to the macroeconomic modeling. In their "financial accelerator" model, the credit market frictions amplifies and propagates aggregate productivity shock to the economy. In their model and the subsequent literature in this area exploits various financial friction on the credit side to show how adverse shocks to the economy may be amplified by worsening financial market conditions. The line of inquiry pursued by several recent papers by Gertler and Kiyotaki (2010), Gertler and Karadi (2011), Gertler et al. (2013),Gertler and 
Kiyotaki (2015), Gertler et al. (2016) introduced realistic banks and internal moral hazard problem to examine it's role in several aspects of financial crisis. However, the common assumption in these papers are bank's are constrained tightly by capital requirements. Since financial intermediaries use a high leverage ratio, sometimes in excess of 10, a tightly constrained bank would amplify any shock, both positive and negative, to its net work by the same factor to its loan origination. This core mechanism is the cornerstone of the entire financial friction literature.

The use of high leverage ratio in banking sector is an empirical observation and it's rationale has received a lot of academic interest. The argument in favor of high leverage posits that a profit maximizing bank can diversify their lending portfolio to reduce risk and thus can produce safe deposit at a lower cost that is used by households that do not participate any other financial market and uses bank deposits to transfer their savings inter temporally. Thus DeAngelo and Stulz (2015), Hanson et al. (2015), Hart and Zingales (2015) and a set of influential literature argues that high leverage is optimal for banks. On the other hand, Admati and Hellwig (2014), Admati et al. (2018) calls attention to the financial distress cost of high leverage and argue that a safer banking system needs much higher capital ratio. Also, empirically in a cross-country study Gambacorta and Shin (2018) shows that 1 percentage point increase in the bank equity-to-total assets ratio is associated with a four basis point reduction in the cost of debt financing and with a 0.6 percentage point increase in annual loan growth. The common assumption in this literature is that banks lever up as much as possible within regulatory prescription because doing so is economically profitable.

However, the data contradicts the above assumptions. Recent empirical evidence by Gropp and Heider (2010) shows banks maintain a high level of discretionary capital over and above the minimum capital requirement. The discretionary capital 
is higher than the buffers that banks hold to insure against falling below the minimum capital requirement. They show that the standard cross-sectional determinants of non-financial firm's capital structures can explain capital structure of large, publicly traded banks in the US and Europe, except for banks close to the minimum capital requirement. SIFIs are the ones who hold capital close to the minimum required level.

The paper rest of the paper is organized as follows: the second part is a selective literature review of the most relevant papers on financial friction and bank sizes, the third section points to our data sources, the fourth section shows how banks differ in cross section, the fifth section examines if banks are truly constrained by capital requirements, the sixth section examines if the propagation of productivity shock is different across different bank sizes and the final part concludes the paper.

\section{Literature Review}

The first few papers that introduced financial friction in the spirit of costly state verification model of Townsend (1979) into the standard infinite horizon framework was the seminal papers by Carlstrom and Fuerst (1997), and Bernanke et al. (1999). These models focus on credit market friction, where firms have to pay external finance premium for borrowing from credit market. The premium increases as firms use more leverage and the credit market frictions amplifies and propagates aggregate productivity shock to the economy.

Collateral constraint is alternative approach to the external finance premium driven financial accelerator mechanism based on the original idea of Hart and Moore (1994). The seminal paper by Kiyotaki and Moore (1997) posits that the creditworthiness of the borrower and availability of collateral affects amount of loans and thus 
propagate and amplify productivity shocks.

These models of financial frictions didn't have an explicit role for banks. The friction was used on the demand side of credit and financial contracts are arranged directly in the financial market under the known form of a contract for the acquisition of external funding.

The DSGE literature introducing a banking sector explicitly taking into account information asymmetry inside a bank and several features of its balance sheet happened only after the financial crisis of 2007-2012. The current research on macroeconomic models with a banking sector examining the role of banks and its behavior are a series of seminal contribution by Goodfriend and McCallum (2007), Gertler and Karadi (2011), Gertler and Kiyotaki (2010), Gertler et al. (2013), Gertler and Karadi (2015), Gertler and Kiyotaki (2015), Gertler et al. (2016). These papers add various financial frictions to account for differences between the interbank interest rate and other short rates, role of monetary policy actions, monetary policy transmissions and Fed's unconventional policy instruments during the financial crisis.

The common assumption in all of these papers is the fact that banks are constrained by capital requirements arising from either internal moral hazard problems or external regulatory requirement. The role of bank size in determining bank capital structure, the empirical evidence of discretionary capital in excess of regulatory requirement or differential regulatory treatment towards bank of different sizes has not received any attention in the current literature.

The first theoretical paper to do so is by Davila and Walther (2017). The authors examine how large and small banks make funding decisions when the government provides system-wide bailouts to the financial sector. They show that bank size, purely on strategic grounds, is a key determinant of banks' leverage choices, even when bailout policies treat large and small banks symmetrically. In their article, large 
banks always take on more leverage than small banks because they internalize that their decisions directly affect the government's optimal bailout policy. In equilibrium, small banks also choose strictly higher borrowing when large banks are present, since banks' leverage choices are strategic complements. Overall, the presence of large banks increases aggregate leverage and the magnitude of bailouts. They show that the optimal ex-ante regulation features size-dependent policies that disproportionally restrict the leverage choices of large banks as increase in the share of assets held by the largest bank is associated with a higher aggregate debt-to-asset ratios.

Optimal bank capital structure received a lot of theoretical attention especially in the spirit of bank run model by Diamond and Dybvig (1983). However, there is scant empirical evidence for the effect of size on bank capital structure decisions. The only empirical paper which touches upon this question is by Gropp and Heider (2010). The authors show, contrary to current theoretical understanding, mispriced deposit insurance and capital regulation are of second-order importance in determining bank capital structure of large U.S. and European banks during 1991 to 2004. They show that standard cross-sectional determinants of non-financial firms' leverage carry over to banks, except for banks whose capital ratio is close to the regulatory minimum. Consistent with a reduced role of deposit insurance. The paper documents a shift in banks' liability structure away from deposits towards non-deposit liabilities. Also the authors find that unobserved time-invariant bank fixed-effects are ultimately the most important determinant of bank capital structures and that bank leverage converges to bank specific, time-invariant targets. This shows that underlying bank-specific characteristics affect the capital structure decisions which may not be explained by the current modeling techniques and calls for a re-evaluation of what I know about optimal level of bank capital. 


\section{Data source}

I have used various publicly available data sources as described below.

Bank data. The bank data is from U.S. Call Reports provided by the Federal Reserve Bank of Chicago from WRDS Bank Regulatory database. I make several changes to make the definition of data consistent across time as suggested by Drechsler et al. (2017). The data is from January 1994 to December 2013. It contains quarterly data on the income statements and balance sheets of all U.S. commercial banks.

Deposit holdings. The data on deposit quantities is from the Federal Deposit Insurance Corporation (FDIC) available using WRDS Bank Regulatory database. The data covers the universe of U.S. bank branches at an annual frequency from June 1994 to June 2014.

Interest Rates. The interest rate data is from WRDS RATES database is based upon the Federal Reserve Board's H.15 release that contains selected interest rates for U.S. Treasuries and private money market and capital market instruments. All rates are reported in annual terms. Daily figures are for Business days and Monthly figures are averages of Business days unless otherwise noted. The data is from January 1994 to December 2013.

Macroeconomic Data. The macroeconomic data is retrieved from Valerie Ramey's website.The author has made available the data and codes used in the paper Ramey (2016). The data contains quarterly macroeconomic data between 1947Q1 and 2015Q4. It contains nominal and real data on GDP, nominal consumption, total investment, nonresidential investment, hours worked, output and output per hour in private business, relative price of investment goods, total population, interest rates on BAA bond, 10 year Treasury bond, 3-month Treasury 
bill and stock prices, from Shiller and Fama-French among several other variables. TFP Data. Total factor productivity data is created by John Fernald and obtained from Federal Reserve Bank of San Francisco. Fernald (2014) shows the methodology for creating a real-time, quarterly series on total factor productivity (TFP) for the U.S. business sector, adjusted for variations in factor utilization labor effort and capital's workweek. I use quarterly data between 1947Q1 and 2015Q4 for estimating economy wide impulse response and data between 1994Q1 and 2013Q4 to merge with bank data.

\section{Bank Characteristics and Summary Statistics}

Prudent management of banks and other financial institutions is important as depositors are generally small unsophisticated investors each typically maintaining a single banking relationship. On failure of a scheduled commercial bank, the government (through FDIC) compensates the depositors and is liable for the cost. Thus it is important for regulators these institutions maintain enough capital to avoid moral hazard problems and ensure continuation even under adverse economic condition.

Internationally the bank capital requirements is set by the Basel Accords. The Basel framework mandates the banks to maintain a minimum capital adequacy ratio. The capital adequacy ratio is the minimum required percentage of a bank's capital to its risk-weighted assets. In the United States, a bank holding company must have a Tier 1 capital ratio of at least 4\%, a combined Tier 1 and Tier 2 capital ratio of at least $8 \%$, and a leverage ratio of at least $4 \%$. These requirements ensures that the banks cannot take excess leverage and become insolvent. In addition to capital requirements which govern the liability side of the balance sheet, there are reserve requirements, which govern the assets side of a bank's balance sheet. The reserve 
requirement is minimum required percentage of cash or highly-liquid assets to its total assets.

In addition to Basel accords, all US banking institutions above the size of 10 billion USD are subjected to stress test since the financial crises in 2007-2009 as part of the Comprehensive Capital Analysis and Review (CCAR) and the Dodd-Frank Wall Street Reform and Consumer Protection Act ("Dodd-Frank Act"). A bank stress test is a simulation of the balance sheet of that institution under baseline, adverse and severely adverse macroeconomic scenarios. Each scenario includes economic variables, including macroeconomic activity, unemployment, exchange rates, prices, incomes and interest rates. These ensure that financial institutions have well-defined and forward-looking capital planning processes that account for their unique risks and sufficient capital to continue operations through times of economic and financial stress. Also using CCAR Federal Reserve restricts bank's capital distributions, such as dividend payments or stock repurchases.

I use bank data from 1983Q1 to 2013Q4 and calculate several capital structure ratios for these banks. I create 10 quantiles of banks according to their asset size in each quarter. Next I use the time-average of these ratios in each decile to find the decile average that is plotted. Given 1.6 million observations across bank and quarters, it is expected that simple averaging will show no pattern across deciles. However, the following summary statistics and graphs are really revealing.

The figure 1 graphs average equity to asset by size decile show a steep downward pattern across deciles. The banks in smallest size deciles hold $13 \%$ equity against the total asset. The largest banks maintain an average equity to asset ratio of 0.08 . $8 \%$ is also the minimum capital requirement according to BASEL III. The decile averages are perfectly monotonic and downward sloping between the lowest and the highest deciles. Hence it is evident that banks in smallest size deciles hold equity in 


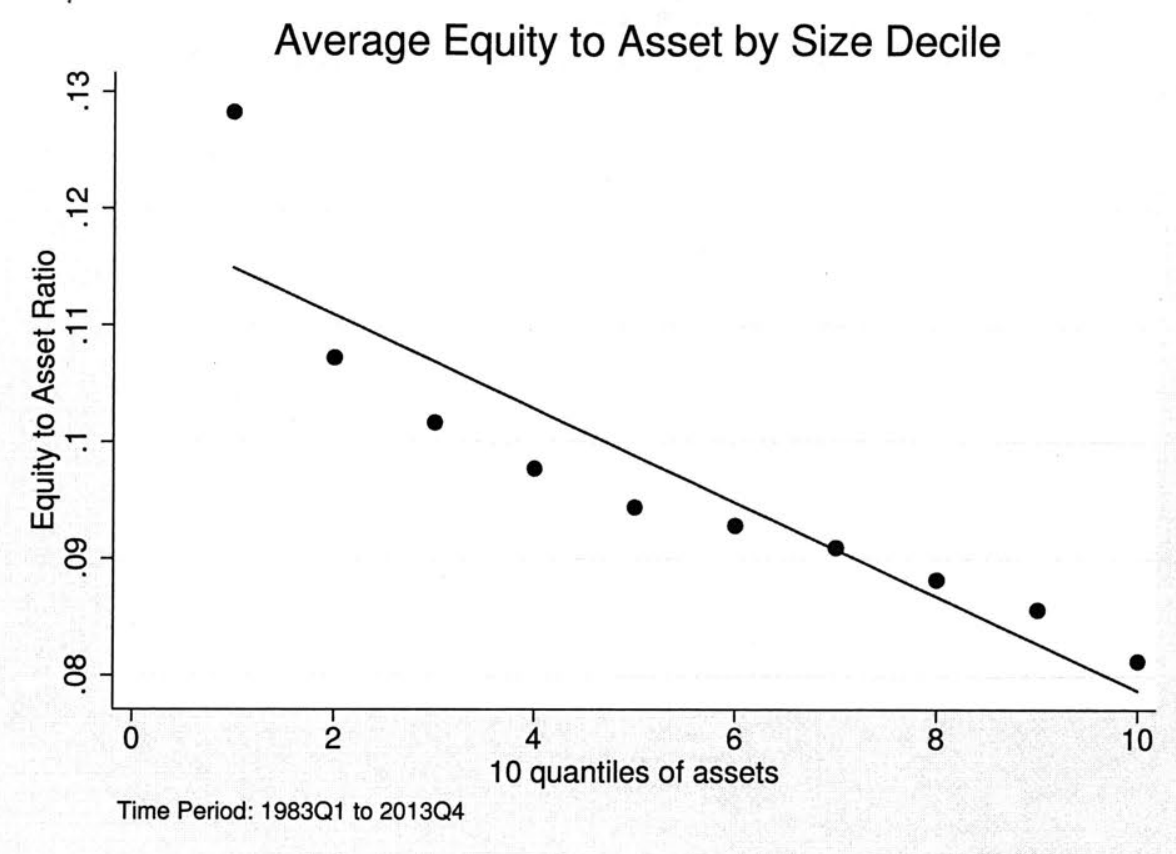

Figure 1: Average Equity to Asset Ratio by Size Decile

excess of minimum capital requirement. This makes sense as the smallest banks are also the riskiest and the optimal capital structure would require them to trade off between costs of bank distress and the liquidity creation. This explanation follows from the seminal paper by Diamond and Rajan (2000).

The figure 2 graphs average book leverage ratio by size decile, average interest income and interest expense and average net interest margin. The relationship for average book leverage ratio is monotonically increasing in size. This is expected given its negatively related to equity to asset ratio. However the other relationships are not monotonic and shows interesting pattern. The average interest income varies between $6.8 \%$ and $7.5 \%$. The interest income is calculated as total interest income over total assets. The income increases up to decile 3 and then steadily decile until it suddenly jumps for the largest bank decile. The difference is statistically significant. 

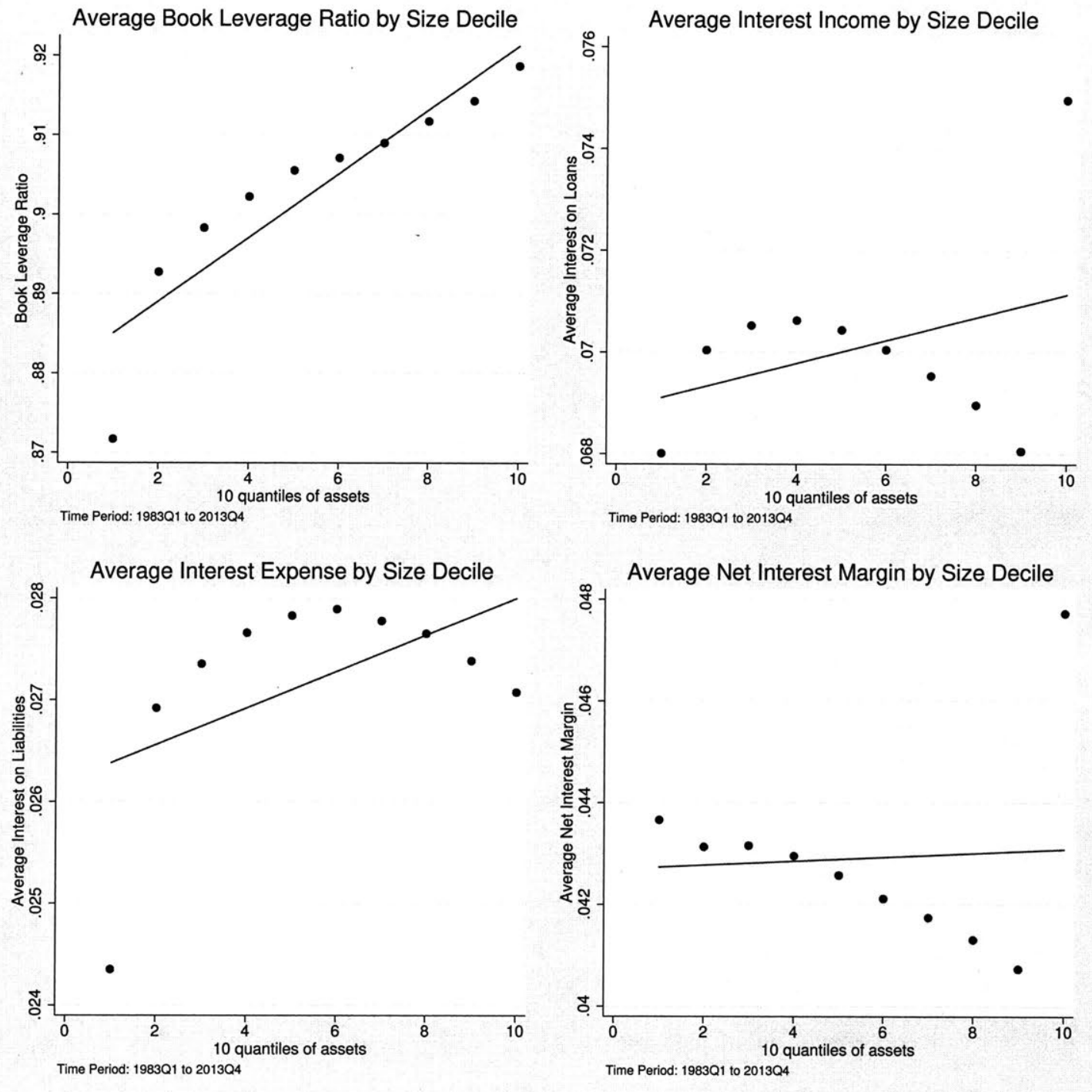

Figure 2: Average Leverage, Interest Income, Interest Expense and NIM by Size Decile 
The average interest expense is calculated as the total interest expense over total liabilities. The average interest expense increases from decile- 1 to decile- 6 and then falls. The range of interest expense is between $2.4 \%$ and $2.8 \%$. Due to outlier nature of the interest income, the net interest margin (NIM) is the highest for the largest banks. The relationship between net interest margin and size is negative and NIM falls steadily as size increases for all the other deciles.

The figure 3 graphs several other capital structure ratios by size decile. Average loan to asset ratio is monotonically increasing in size and varies between 0.5 and 0.6. Average deposit to asset ratio doesn't show a clear pattern and varies between 0.84 and 0.88. Average non-deposit liabilities is monotonically increasing in size. These observation is in line with Gropp and Heider (2010) which shows that the largest banks use higher non-deposit liabilities compared to smaller banks. The average non-deposit liabilities for banks in decile-10 is 0.1 whereas banks in lower deciles raise non-deposit liabilities an average of 0.02 times their total assets.

The Tier 1 capital ratio is the ratio of a bank's core equity capital to its total risk-weighted assets (RWA). Risk-weighted assets are the total of all assets held by the bank weighted by credit risk, components for market risk and operational risk. Tier-1 capital to risk-weighted asset is monotonically decreasing in size. This is an important observation. The largest banks maintain the lowest Tier-1 capital to risk-weighted asset even though the BASEL-III mandates minimum total lossabsorbing capacity (TLAC) requirement to be the highest for these banks. The lowest size banks maintain a Tier-1 capital ratio close to $25 \%$ where as the largest banks maintain a ratio close to $15 \%$. However, even then the ratio is higher than the TLAC requirements for the largest banks.

Table 1 provides summary statistics for all banks in the entire panel data (1983Q1 to 2013Q4). We find that the mean of book leverage is 0.9 with a standard deviation 

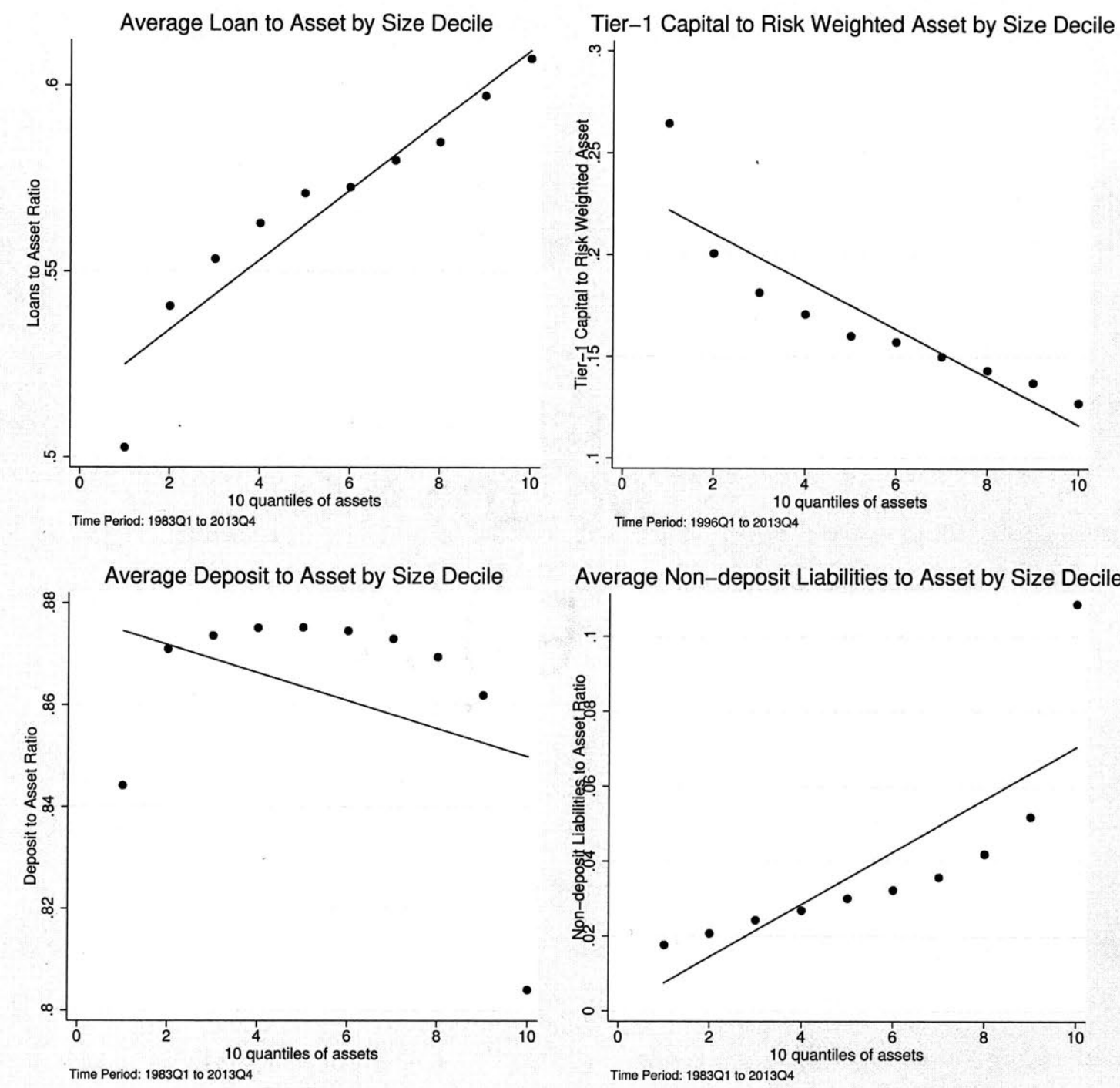

Average Non-deposit Liabilities to Asset by Size Decile

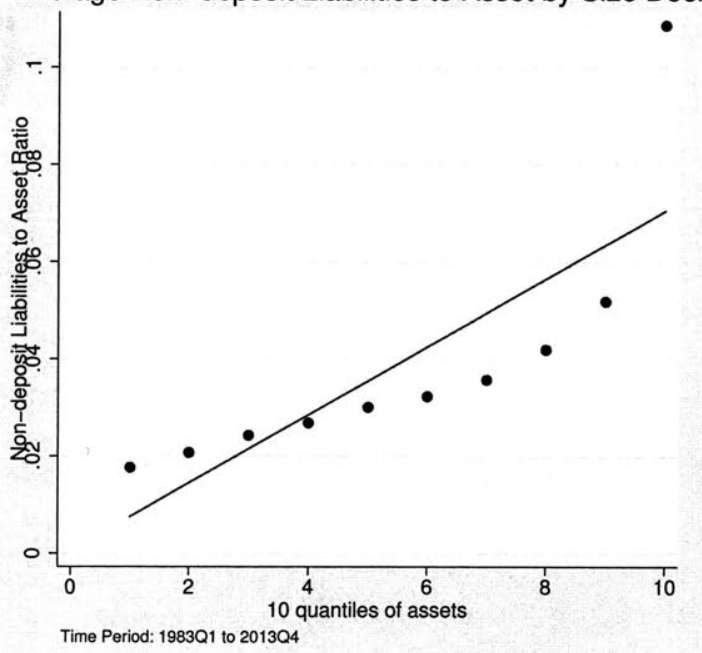

Figure 3: Average Loan to Asset, Tier-1 Capital to Risk Weighted Asset, Average Deposit to Asset and Average Non-Deposit Liabilities to A byt Size Decile 
of 0.039 . There is a variability in book leverage across banks. Interestingly, Tier-1 capital to RWA ratio has a mean of 0.169 and a SD of 0.109 . The variance in Tier-1 capital ratio is especially large which shows banks are likely not constrained by the regulatory requirements on this ratio.

Table 2 provides summary statistics for the subset of banks in the highest decile and the highest percentile (1983Q1 to 2013Q4). I find that the mean of book leverage is 0.9 with a standard deviation of 0.039 . There is a variability in book leverage across banks. Interestingly, Tier-1 capital to RWA ratio has a mean of 0.169 and a SD of 0.109. The variance in Tier-1 capital ratio is especially large which shows banks are likely not constrained by the regulatory requirements on this ratio. Looking at the highest deciles of banks it is elear interest earned on loans, book leverage, loan to asset ratio, NIM is higher than average. whereas equity to asset ratio and Tier-1 capital to risk weighted capital is lower.

\section{Investment Cash Flow Sensitivity of Banks}

I show in the previous section that, on average, large banks maintain lower equity to asset ratio and Tier 1 capital to risk weighted asset ratio. As these ratios are indeed close to the minimum capital requirements, equity remaining unchanged large banks cannot increase their deposits and loans without falling below the capital requirements. Thus only when bank capital increases, banks can issue new deposit and make new loans which were otherwise not possible. Therefore when capital requirements constraint binds, the deposits and loans should be more sensitive to internal cash flow generated by the banks. As internal cash flows increase bank capital, banks would be able borrow more by issuing more deposits. They would also deploy these two sources of funds, net profit and additional borrowing, to lend 


\begin{tabular}{lrrrrr}
\hline \hline & & & & & \\
& Obs & Mean & SD & Mean & Max \\
\cline { 2 - 6 } Ratios: & & & & & \\
Interest Earned on Loans & $1,605,645$ & 0.070 & 0.046 & 0.000 & 0.145 \\
Interest Expense on Deposits & $1,609,490$ & 0.027 & 0.023 & 0.000 & 0.078 \\
Book Leverage & $1,609,476$ & 0.903 & 0.039 & 0.693 & 0.960 \\
Loan to Asset Ratio & $1,609,474$ & 0.567 & 0.150 & 0.143 & 0.875 \\
Equity to Asset Ratio & $1,609,474$ & 0.088 & 0.045 & 0.071 & 0.254 \\
Deposit to Asset Ratio & $1,609,476$ & 0.862 & 0.075 & 0.448 & 0.944 \\
Non-deposit to Asset Ratio & $1,609,476$ & 0.039 & 0.056 & 0.000 & 0.333 \\
Tier1 Capital to Risk Weighted Capital & 548,318 & 0.169 & 0.109 & 0.073 & 0.849 \\
Net Interest Margin to Asset Ratio & $1,605,640$ & 0.043 & 0.029 & 0.000 & 0.126 \\
Balanace Sheet: & & & & & \\
Assets (USD Million) & $1,609,479$ & 186.1 & 569.3 & 3.5 & 4634.0 \\
Net Interest Margin (USD Million) & $1,148,463$ & 2.3 & 7.1 & 0.0 & 58.1 \\
Deposits (USD Million) & $1,609,478$ & 142.6 & 392.7 & 2.6 & 3123.0 \\
Loans (USD Million) & $1,609,476$ & 114.2 & 355.3 & 1.1 & 2878.0 \\
Equity (USD Million) & $1,609,478$ & 16.3 & 47.7 & 0.3 & 386.6 \\
\hline
\end{tabular}

Table 1: Summary Statistics for All Banks in the entire Panel Data (1983Q1 to 2013Q4) 


\begin{tabular}{lrrrrrr}
\hline \hline & \multicolumn{3}{c}{ Highest Decile } & \multicolumn{3}{c}{ Highest Percentile } \\
\cline { 2 - 7 } & Obs & Mean & SD & Obs & Mean & SD \\
Ratios: & & & & & & \\
Interest Earned on Loans & 160,708 & 0.075 & 0.042 & 16014 & 0.092 & 0.030 \\
Interest Expense on Deposits & 160,871 & 0.027 & 0.023 & 16014 & 0.027 & 0.024 \\
Book Leverage & 160,871 & 0.919 & 0.030 & 16014 & 0.926 & 0.032 \\
Loan to Asset Ratio & 160,871 & 0.607 & 0.140 & 16014 & 0.602 & 0.142 \\
Equity to Asset Ratio & 160,871 & 0.082 & 0.030 & 16014 & 0.077 & 0.024 \\
Deposit to Asset Ratio & 160,871 & 0.804 & 0.116 & 16014 & 0.655 & 0.137 \\
Non-deposit to Asset Ratio & 160,871 & 0.109 & 0.095 & 16014 & 0.237 & 0.096 \\
Tier1 Capital to Risk Weighted Capital & 54,800 & 0.127 & 0.069 & 5449 & 0.108 & 0.052 \\
Net Interest Margin to Asset Ratio & 160,708 & 0.048 & 0.031 & 16014 & 0.064 & 0.034 \\
\hline Balanace Sheet: & & & & & & \\
Assets (USD Million) & 160,871 & $1,212.0$ & $1,413.8$ & 16014 & $4,017.9$ & $1,112.6$ \\
Net Interest Margin (USD Million) & 114,791 & 15.4 & 17.6 & 11422 & 53.1 & 11.3 \\
Deposits (USD Million) & 160,871 & 872.3 & 948.5 & 16014 & $2,655.7$ & 789.4 \\
Loans (USD Million) & 160,871 & 747.3 & 884.4 & 16014 & $2,432.6$ & 763.8 \\
Equity (USD Million) & 160,871 & 99.4 & 119.0 & 16014 & 309.7 & 112.9 \\
\hline
\end{tabular}

Table 2: Summary Statistics for Banks in Highest Decile and Highest Percentile in the entire Panel Data (1983Q1 to 2013Q4) 
more.

In this section, I establish the effect of regulatory constraint on bank lending and deposit taking behavior controlling for lending opportunities. Our goal is to show that the large banks are more constrained on their lending and deposit taking than smaller banks due to the binding capital ratio regulations. The empirical strategy is to show that both deposit cash flow sensitivity and lending cash flow sensitivity are higher for larger banks.

This strategy is similar to Fazzari et al. (1988) investment cash flow sensitivity analysis for manufacturing firms. Due to asymmetric information in credit markets, more constrained firms use internal capital as the source of funds for investments and has a higher investment cash flow sensitivity controlling for lending opportunities. They use three different proxies for lending opportunities in different empirical specifications - Tobin's Q, the market value of the assets to the book value; sales accelerator, the fluctuations in sales relative to firm's equity; and a combined measure of output and the cost of capital.

In our case, I use two different proxies for bank lending opportunities in different empirical specifications. The first proxy is the spread between 10 year constant maturity government bond rate and 3 months treasury bill rate. As banks issue shorter maturity liabilities to fund longer maturity loans, the spread is reflective of lending opportunities available to all the banks but it does not reveal the cross sectional heterogeneity across banks. The second proxy is the net interest margin (NIM), defined as the ratio of net interest income to total assets less net interest expenses on deposits. NIM determines the profitability of bank lending and reflects the cross sectional heterogeneity across banks. 
I estimate the following models in the panel data:

$$
\left(\frac{I}{K}\right)_{i t}=\alpha_{i}+\delta_{t}+\sum_{j=1}^{10} \beta_{j} \text { Size-Decile }_{j} \times\left(\frac{C F}{K}\right)_{i t}+\gamma X_{i t}+\epsilon_{i t}
$$

where $I_{i t}$ represents loans for bank $i$ during period $t$ in the first specification, deposits in the second specification. $C F_{i t}$ represents the net profit earned by bank $i$ during period $t$. Both right and left hand side variables are scaled by bank capital $K_{i t}$. I interact this variable with 10 size deciles for each bank. Size decile indicates the decile bank $i$ belongs to according to bank asset size at time $t$. $X$ represents the control for lending opportunity. The first set of regressions use bond spread as the proxy which has no cross sectional heterogeneity at each time period $t . \alpha_{i}$ are bank fixed effects and $\delta_{t}$ are time fixed effects. I cluster standard errors at the bank level.

To ensure that the regression results are not driven by the size of the banks, I scale both the dependent variable using bank capital. The same can be done using bank assets as scaling factor. But I stay as close to Fazzari et al. (1988) specification as possible. To facilitate interpretation, I scale the dependent variables by 100 .

Hypotheses. I expect to see similar coefficients on loan and deposit growth in response to increasing net profit across different size deciles if all banks are equally capital constraint. I do not expect to see any discernible pattern on the coefficients when sorted on the basis of size.

Results. The results are presented in the following tables.

In table 3 I report the regression results for quarterly loans and deposits on net profit controlling for bond spread as investment opportunity. The first set of regressions are contemporaneous. In the next set of specifications I use next quarter lending and borrowing as the dependent variable.The stars on the coefficients show levels of significance: for p-value is less than 0.1 , it is flagged with one star $\left(^{*}\right)$, for 
p-value is less than 0.05 , it is flagged with two stars $\left(^{* *}\right)$ and finally a p-value is less than 0.01 , it is flagged with three stars $(* * *)$. Standard errors of the coefficients are shown in the parentheses.

In table 4 I report the regression results for quarterly loans and deposits on net profit controlling for NIM as investment opportunity. Like previous table results for contemporaneous and next quarter lending and borrowing is reported. I follow the same convention for statistical significance.

According to table 3 , for the smallest banks in decile-1, every dollar increase in net profit increases the loan issuance by 38 cents contemporaneously and issue 51 cents more deposit. A dollar increase in net profit in the previous period, also contributes to 32 cents increase in loan and 43 cents increase in deposits in the next period. All the coefficients are statistically significant at the level of $1 \%$. This implies the banks in this decile are constrained by the capital requirements. As the net profit increases and the bank capital is improved after paying dividends, they can issue more deposit and thus lend more. However, for every dollar increase in capital, banks can increase the deposits by close to 10 times. Here I see that the increase in deposits is less than a dollar on the net profit. The same numbers increase to 51 cents per dollar in loan and 56 cents per dollar in deposits for banks in 10th decile.

If I look at the coefficients for contemporaneous loan on size in column (1) of table 3 are monotonically increasing. This means larger the bank issue more loan contemporaneously as their net profit number increases. The difference between 10th decile and 1st decile is statistically significant in t-test. The result is exactly similar in column (3) for next quarter loan issuance. This is an indirect evidence that larger banks are more capital constrained. As the bank capitals increase larger banks increase their loan volume more than smaller banks both contemporaneously and in the next period. These results cannot be explained by investment opportunities as I 
control for investment opportunities using 10-year bond spread.

In the column (2), the coefficients on contemporaneous deposits increase with size up to 8 th decile and then decreases in decile 9 and 10. This shows as profits improve the bank capital, larger banks choose to issue more deposits, however banks in largest deciles can also issue more non-deposit liabilities. This similar results are obtained for next quarter deposits as well in column (4). All the coefficients are statistically significant at $1 \%$ level of significance.

In the previous table, investment opportunity is controlled by 10-year bond spread which is same in the cross-section. To distinguish between differential investment opportunities available to different banks, I construct NIM variable for each bank. In table 4, I control the investment opportunity using NIM-variable. In column (1) and column (3), the results are similar to the results obstained in 3. However, the coeffficents on loan growth across size in both contemporaneous and one-period in the future are not monotonically increasing anymore. Possibly because NIM is so high in the last two deciles, its coefficient captures some of the increase in loan growth due to increase in bank capital. All the coefficients are statistically significant at $1 \%$ level of significance.

In column (2) and column (4), the coefficients on deposits show similar pattern that of column (1) and (3). As size increases, the deposit growth increases with size from 56 cents per dollar in decile- 1 to 65 cents per dollar in decile- 8 . However, in the largest two deciles, banks increasingly rely on non-deposit liabilities, hence the coefficients dip. However all the coefficients are statistically significant at $1 \%$ level of significance.

There are several ways, this estimates can be improved. Using post-tax and post-dividend net profit as independent variable would directly make the coefficients indicative of tightness of capital constraint. The coefficients will likely be larger than 
reported. However, bank fixed effects should be able to absorb some of the differences if I assume the banks keep the dividends almost constant.

This results are strongly suggestive of the fact that smaller banks are far less constrained than the larger banks. None of the banks increase the loan dollar for dollar contemporaneously or issue deposit in the multiples of leverage ratio as the capital increases. This is in stark contrast with macroeconomic models which use a mechanism that amplifies shocks to net worth in the multiples of leverage ratio and propagate that shock to bank's loan portfolio.

\section{Estimating Impulse Response in the Data}

Financial accelerator model shows a mechanism by which adverse productivity shocks to the economy gets amplified by the financial markets. Seminal papers by Bernanke et al. (1999), Carlstrom and Fuerst (1997) posits that the external finance premium in the credit market, defined by the difference between the cost of external borrowing and the opportunity cost of internal funds, has a negative relationship with the productivity shock. The external finance premium in the economy is difficult to quantify. The usual proxy is the difference between the interest rate on loans and the marginal cost of funds for banks, i.e., bank's price-cost margin. The usual assumption is that bank's cost reflects the opportunity cost of firms internal capital and bank's price is the interest rate on loans made to the firms.

There is some empirical evidence of countercyclical price-cost margins in the US and European banking. Aliaga-Díaz and Olivero (2010) uses VAR analysis to measure the comovement between bank margins and output in a panel data for the US banks and show margins are countercyclical with respect to GDP and bank loans after controlling for monetary policy and credit risk. Altunbaş et al. (2016) reports 
countercyclicality of banks' price - cost margins in a panel dataset of European banks.

However, given our previous exposition on how bank size has an effect on its capital structure decisions, it's funding cost and return on lending opportunities, I need to re-examine this counter-cyclical price-cost margin across different bank sizes. This is particularly relevant for policy implications that talk about even stricter capital requirements as policy tool. If all banks already maintain capital in excess of the regulatory minimum and do not adjust the shock to its net worth immediately by passing it to the loan portfolio, the policy tool may be ineffective or in some cases, counter productive.

I do two experiments in the following sections, first we look at the aggregate economy and examine banks role in financial acceleration. In the next set of tests I look at impulse response of several price-cost and loan portfolio variables to the capitalization-adjusted technology factor productivity shock (TFP) across different bank sizes.

\subsection{IRF in Aggregate Time Series Data}

In this section I estimate the impulse response to a TFP shock in aggregate time series data on a number of endogenous variables of interest. The real variables include output (GDP), consumption and total credit to nonfinancial sectors. The price variables include short term interest rate (the 3 month TBill rate), FED funds

rate, and three measures of price-cost margin - net interest margin, the 10-year constant maturity bond spread over the 3 months TBill rate and the BAA corporate bond spread. Although our interest lies in estimating impulse response of price-cost margin, I show the results in conjuction with other output variables to point out cyclicality of the response. 


\begin{tabular}{lrr|rr}
\hline \hline & $(1)$ & $(2)$ & $(3)$ & $(4)$ \\
Cash Flow & Loan $_{t}$ & Deposits $_{t}$ & Loan $_{t+1}$ & Deposits $_{t+1}$ \\
\hline Size Decile 1 & $38.8134^{* * *}$ & $51.4505^{* * *}$ & $32.2093^{* * *}$ & $43.3450^{* * *}$ \\
& {$[0.378]$} & {$[0.492]$} & {$[0.402]$} & {$[0.506]$} \\
Size Decile 2 & $42.7859^{* * *}$ & $55.6187^{* * *}$ & $36.3619^{* * *}$ & $47.4906^{* * *}$ \\
& {$[0.293]$} & {$[0.370]$} & {$[0.313]$} & {$[0.381]$} \\
Size Decile 3 & $45.0730^{* * *}$ & $57.3380^{* * *}$ & $38.7090^{* * *}$ & $49.1782^{* * *}$ \\
& {$[0.260]$} & {$[0.334]$} & {$[0.276]$} & {$[0.340]$} \\
Size Decile 4 & $46.4626^{* * *}$ & $58.5742^{* * *}$ & $40.1408^{* * *}$ & $50.2897^{* * *}$ \\
& {$[0.243]$} & {$[0.319]$} & {$[0.259]$} & {$[0.325]$} \\
Size Decile 5 & $47.7250^{* * *}$ & $59.7490^{* * *}$ & $41.5102^{* * *}$ & $51.5097^{* * *}$ \\
& {$[0.239]$} & {$[0.317]$} & {$[0.251]$} & {$[0.321]$} \\
Size Decile 6 & $48.6486^{* * *}$ & $60.4535^{* * *}$ & $42.3855^{* * *}$ & $52.0600^{* * *}$ \\
& {$[0.247]$} & {$[0.328]$} & {$[0.258]$} & {$[0.330]$} \\
Size Decile 7 & $49.5104^{* * *}$ & $61.0550^{* * *}$ & $43.2405^{* * *}$ & $52.6275^{* * *}$ \\
Size Decile 8 & {$[0.255]$} & {$[0.348]$} & {$[0.266]$} & {$[0.346]$} \\
& $50.1067^{* * *}$ & $60.9780^{* * *}$ & $43.8443^{* * *}$ & $52.4072^{* * *}$ \\
Size Decile 9 & {$[0.286]$} & {$[0.404]$} & {$[0.294]$} & {$[0.396]$} \\
& $50.6489^{* * *}$ & $59.9968^{* * *}$ & $44.4026^{* * *}$ & $51.4170^{* * *}$ \\
Size Decile 10 & {$[0.316]$} & {$[0.466]$} & {$[0.327]$} & {$[0.451]$} \\
& $50.6553^{* * *}$ & $56.1440^{* * *}$ & $44.4026^{* * *}$ & $47.6681^{* * *}$ \\
& {$[0.414]$} & {$[0.724]$} & {$[0.427]$} & {$[0.668]$} \\
Observations & 1148277 & 1148280 & 1129387 & 1129389 \\
Bank FE & Yes & Yes & Yes & Yes \\
Quarter FE & Yes & Yes & Yes & Yes \\
R-squared & 0.821 & 0.802 & 0.773 & 0.747 \\
Adjusted R-Sq & 0.818 & 0.799 & 0.77 & 0.743 \\
\hline
\end{tabular}

Table 3: Cash Flow Sensitivity of Bank Loans and Deposits Controlling for 10-Year Bond Spread 


\begin{tabular}{lrr|rr}
\hline \hline & $(1)$ & $(2)$ & $(3)$ & $(4)$ \\
Cash Flow & Loan $_{t}$ & Deposits $_{t}$ & Loan $_{t+1}$ & Deposits $_{t+1}$ \\
\hline Size Decile 1 & $44.5197^{* * *}$ & $56.7030^{* * *}$ & $37.6087^{* * *}$ & $48.2098^{* * *}$ \\
& {$[0.339]$} & {$[0.458]$} & {$[0.376]$} & {$[0.485]$} \\
Size Decile 2 & $48.2264^{* * *}$ & $60.6140^{* * *}$ & $41.5041^{* * *}$ & $52.1135^{* * *}$ \\
& {$[0.268]$} & {$[0.351]$} & {$[0.301]$} & {$[0.376]$} \\
Size Decile 3 & $50.5478^{* * *}$ & $62.3630^{* * *}$ & $43.8719^{* * *}$ & $53.8164^{* * *}$ \\
& {$[0.241]$} & {$[0.320]$} & {$[0.271]$} & {$[0.341]$} \\
Size Decile 4 & $51.9104^{* * *}$ & $63.5829^{* * *}$ & $45.2744^{* * *}$ & $54.9129^{* * *}$ \\
& {$[0.227]$} & {$[0.308]$} & {$[0.255]$} & {$[0.328]$} \\
Size Decile 5 & $53.0896^{* * *}$ & $64.6855^{* * *}$ & $46.5636^{* * *}$ & $56.0640^{* * *}$ \\
& {$[0.221]$} & {$[0.304]$} & {$[0.245]$} & {$[0.320]$} \\
Size Decile 6 & $53.9038^{* * *}$ & $65.2851^{* * *}$ & $47.3357^{* * *}$ & $56.5228^{* * *}$ \\
& {$[0.227]$} & {$[0.312]$} & {$[0.250]$} & {$[0.326]$} \\
Size Decile 7 & $54.5855^{* * *}$ & $65.7353^{* * *}$ & $48.0178^{* * *}$ & $56.9440^{* * *}$ \\
& {$[0.232]$} & {$[0.328]$} & {$[0.253]$} & {$[0.338]$} \\
Size Decile 8 & $55.0314^{* * *}$ & $65.5429^{* * *}$ & $48.4827^{* * *}$ & $56.6197^{* * *}$ \\
Size Decile 9 & {$[0.254]$} & {$[0.375]$} & {$[0.273]$} & {$[0.378]$} \\
& $55.3233^{* * *}$ & $64.3614^{* * *}$ & $48.8120^{* * *}$ & $55.4484^{* * *}$ \\
Size Decile 10 & {$[0.282]$} & {$[0.439]$} & {$[0.303]$} & {$[0.434]$} \\
& $55.1602^{* * *}$ & $60.4152^{* * *}$ & $48.6583^{* * *}$ & $51.6201^{* * *}$ \\
& {$[0.371]$} & {$[0.709]$} & {$[0.393]$} & {$[0.658]$} \\
Observations & $1,144,662$ & $1,144,663$ & $1,125,898$ & $1,125,899$ \\
Bank FE & Yes & Yes & Yes & Yes \\
Quarter FE & Yes & Yes & Yes & Yes \\
R-squared & 0.838 & 0.811 & 0.787 & 0.753 \\
Adjusted R-Sq & 0.835 & 0.808 & 0.784 & 0.749 \\
\hline & & & &
\end{tabular}

Table 4: Cash Flow Sensitivity of Bank Loans and Deposits Controlling for NIM 
Several data measures of TFP shocks are constructed in the literature - Francis et al. (2014); Justiniano et al. (2011); and Fernald (2014) are the three common neutral technology shocks used in Ramey (2016). I consistently use Fernald utilization-adjusted TFP shocks for our analysis. All three measures are highly correlated, but only Fernald shocks are publicly available, real-time updated, quarterly time-series data that adjusts for variations in factor utilization - labor effort and capital's workweek.

I use Jordà (2005) local projection method for estimating the impulse response. This lets us compute impulse responses without specification and estimation of the underlying multivariate dynamic system. I estimate local projections at each period of interest as compared to extrapolating VAR estimates into increasingly distant horizons. The impulse response of $Y$ at horizon $t+h$, is estimated using the following single regression.

$$
Y_{t+h}=\beta_{h}+\beta_{1 h} \epsilon_{a t}+\beta_{2 h}^{\prime} X_{t-1}+\text { Quadratic trend }+u_{t+h}
$$

where $\epsilon_{a t}$ is data measure of productivity shock, Fernald-utilization adjusted shocks in our case. Controls $X_{t-1}$ include two lags each of the shock to absorb any serial auto correlation, log real GDP per capital, log labor productivity and other dependent variables chosen for each $Y$ variable as likely forecasters of $Y_{t+h}$ given time $t-1$ information. Quadratic trend removes both linear and quadratic trend present in the response variable. The coefficient $\beta_{1 h}$ estimates the response of the $Y$ variable to a $1 \%$ productivity shock $h$ quarters after impact, i.e., $\hat{\beta_{1 h}}=\frac{\partial Y_{t+h}}{\partial \epsilon_{a t}}$.

Results. In our estimation using this data and Jordà (2005) estimation technique, impulse response to the Fernald's utilization-adjusted TFP shock results in the usual positive jump as expected for three real variables. GDP, consumption 

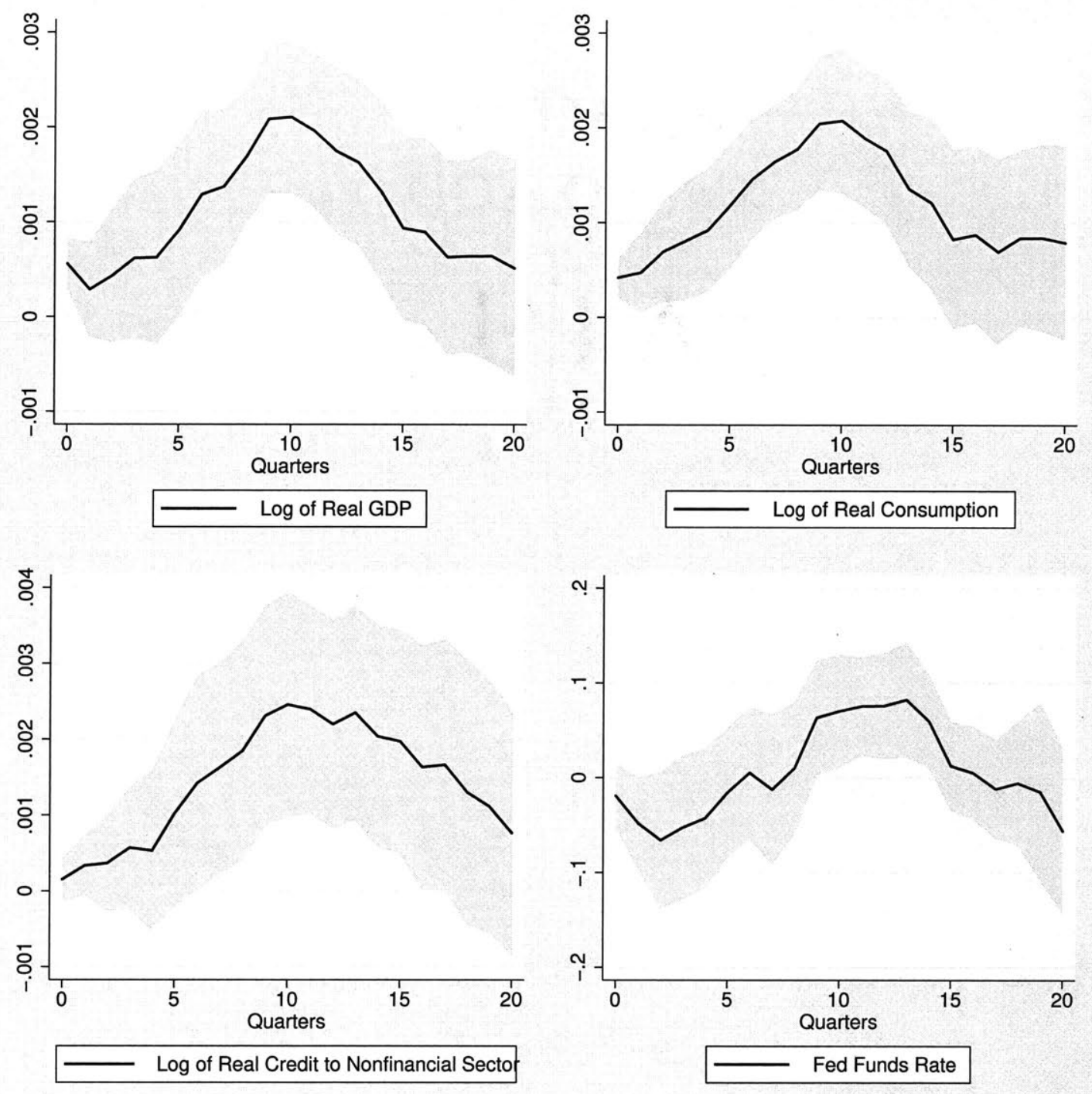

Figure 4: Effects of TFP shock, Jorda local projection, on real variables The figure shows responses of real GDP, real consumption, real credit to nonfinancial sector and the FED Funds rate on Fernald's utilization adjusted TFP growth. Light gray bands are $90 \%$ confidence bands. 

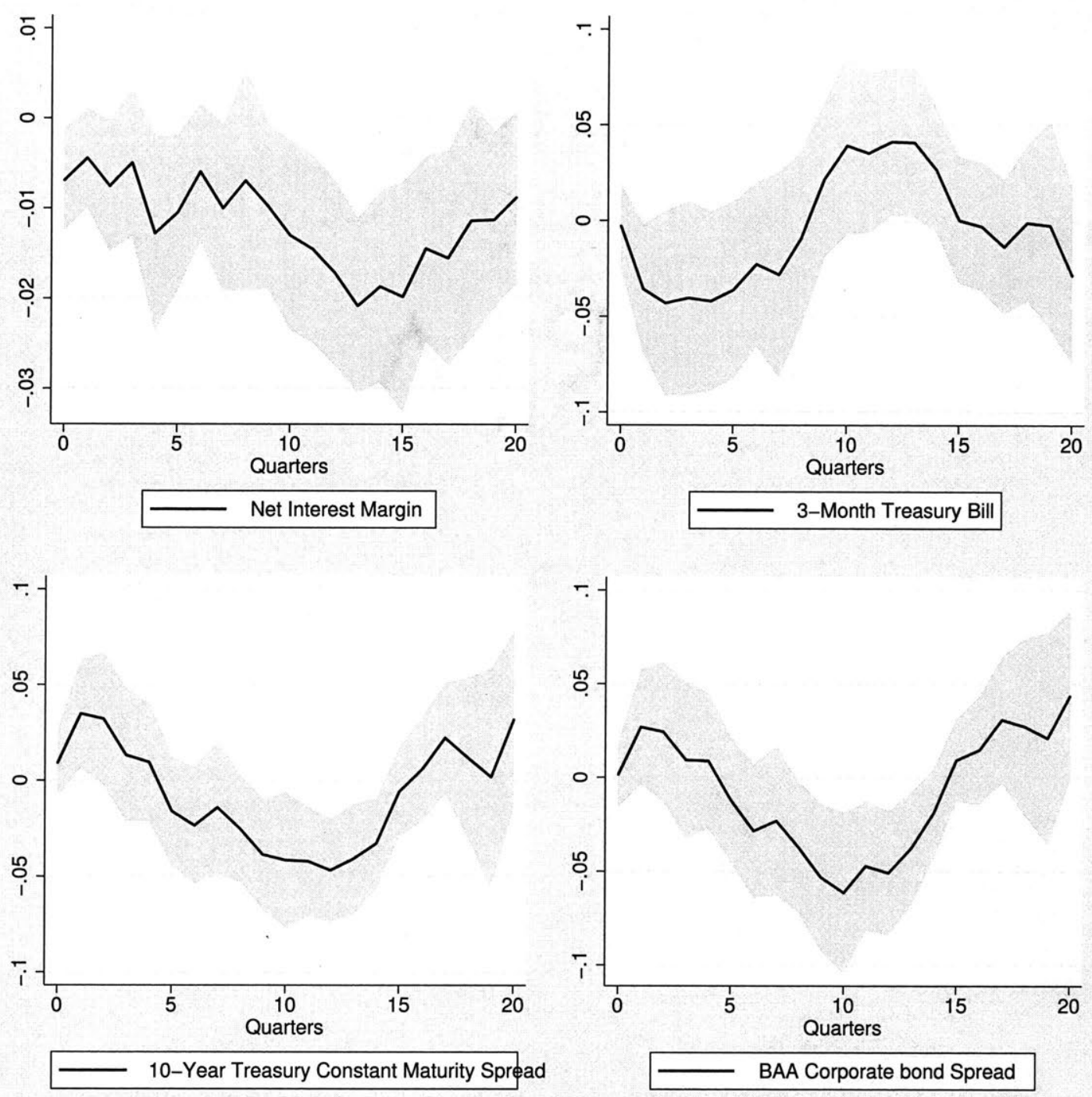

Figure 5: Effects of TFP shock, Jorda local projection, on price cost margin The figure shows responses of short term interest rate (the 3 month TBill rate), net interest margin, the 10-year constant maturity bond spread over the 3 months TBill rate and the BAA corporate bond spread on Fernald's utilization adjusted TFP growth. Light gray bands are $90 \%$ confidence bands. 
shows a delayed jump and a hump-shaped response. Similarly, the credit to nonfinancial sector does not jump immediately and keep on rising till 10-quarters and then returns to normal around 16-20 quarters.

I now look at price-cost margin data using this estimation technique. There is no empirical literature that uses this technique on aggregate data. Aliaga-Díaz and Olivero (2010) uses VAR analysis to measure the comovement between bank margins and output in a panel data for the US banks and show margins are countercyclical with respect to GDP. VAR estimates extrapolate coefficients into increasingly distant horizons.

I use three proxies for price-cost are NIM average of all banks, 10-year treasury constant maturity spread with 3-month treasury bill, BAA bond spread against 3month treasury bill. I find that consistent with the empirical evidences, net interest margin falls immediately and is statistically significant. It continues below the long run average for at least 12-15 quarters before reverting to normal around 20 quarters. However, both the 10-year bond spread and the BAA corporate bond spread jumps up for first 2-3 quarters and then continue falling till 10 quarters and subsequently regress to the mean within 16 quarters.

However, the next two measures of 10-year bond spread and BAA corporate bond spread show interesting results. These are used in the macroeconomic literature as a measure for investment opportunity. 10-year bond spread jumps immediately when a positive TFP shock hits at time- 0 and then starts falling after 1 or 2 quarters. Corporate bond spread is not expected from the financial accelerator model. In response to TFP shocks, the model posits that these rates, which are representative of the external finance premium, should fall immediately. However, in aggregate data, this short upswing is not statistically significant. Hence, in the next section, I re-investigate this dynamics in panel data. 


\subsection{IRF in the Panel Data for US Banking}

In this section I estimate impulse response of several bank specific variables of interest - total loans, interest earned on loans, interest paid on liabilities and average net interest margin to Fernald's utilization adjusted TFP shock.

This estimation is done using panel data for all banks available in call reports maintained with WRDS bank regulatory database. The data definition is made consistent using definitions suggested by Drechsler et al. (2017). I use Jordà (2005) local projection method in panel data.

$$
Y_{t+h}=\beta_{h}+\beta_{1 h} \epsilon_{a t}+\beta_{2 h}^{\prime} X_{t-1}+\text { Quadratic trend }+u_{t+h}
$$

where $\epsilon_{a t}$ is data measure of productivity shock, Fernald-utilization adjusted shocks in our case. Controls $X_{t-1}$ include two lags each of the shock to absorb any serial auto correlation. Quadratic trend removes both linear and quadratic trend present in the response variable. The coefficient $\beta_{1 h}$ estimates the response of the $Y$ variable to a $1 \%$ productivity shock $h$ quarters after impact, i.e., $\hat{\beta_{1 h}}=\frac{\partial Y_{t+h}}{\partial \epsilon_{a t}}$.

To contrast between banks which are truly constrained by regulatory capital requirements. I split the sample in two: in the first sub-sample I include all banks except 10th size decile, the other sub-sample is the banks comprising of 10th size decile.

Results. In our estimation using this data and Jordà (2005) estimation technique, impulse response to the Fernald's utilization-adjusted TFP shock results in the usual positive jump as expected for three real variables. GDP, consumption shows a delayed jump and a hump-shaped response. Similarly, the credit to nonfinancial sector does not jump immediately and keep on rising till 10-quarters and then returns to normal around 16-20 quarters. 
I now look at price-cost margin data using this estimation technique. There is no cmpirical literature that uses this technique on aggregate data. Aliaga-Díaz and Olivero (2010) uses VAR analysis to measure the comovement between bank margins and output in a panel data for the US banks and show margins are countercyclical with respect to GDP. VAR estimates extrapolate coefficients into increasingly distant horizons.

Figure 6 shows the result of the impulse response in the panel data. The results are interesting for the highest decile as it contradicts the typical assumptions in the macrocconomic models.

For the total bank loan portfolio, in case of all banks except the highest decile, the response is an immediate jump to 5 basis points within first 4 quarters and then returns to normal 8-10 quarters. However, in case of the banks in highest decile, the loan portfolio falls by 10 basis points on 1 percentage point TFP shock and for 9 quarters stay below the equilibrium level and returns to normal in quarter 10.

The results for interest earned shows an interesting pattern, for banks in first 9 deciles, the interest earned shows a initial jump of 6 basis points and falls below normal after 4 quarters and stays below normal for at least 10 quarters. The interest earned on loans show a lesser jump of 4 basis points and falls below normal after 4 quarters and stays below normal for at least 10 quarters.

The results for interest paid on liabilities is completely bunched together for both sub-samples. The results show a jump of 5 basis points within first 2 quarters for a $1 \%$ TFP shock. It stays above normal for 6 quarters and falls to -5 basis points after 8 quarters.

The results for average NIM follows similar shape in both sub-samples. However, for the first 9 deciles, average NIM jump to 2 basis points for a $1 \%$ TFP shock and for the highest decile it falls by 2 basis points immediately. Following this both follows a 

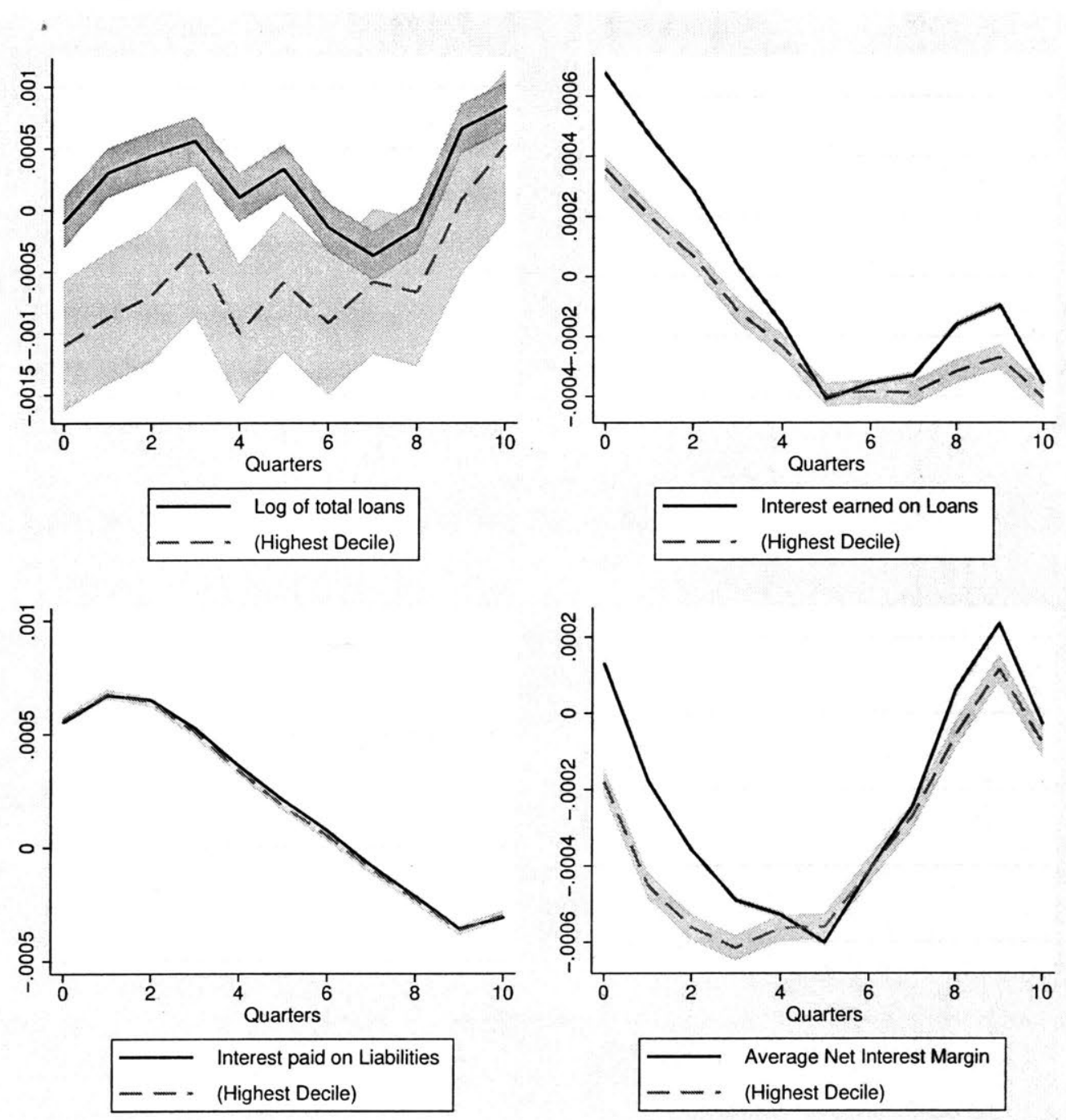

Figure 6: Effects of TFP shock, Jorda local projection, on total loans, interest income, interest expense and average NIM

The figure shows responses of total banks loans, interest earned on loans, interest paid on liabilities and average net interest margin on Fernald's utilization adjusted TFP growth. Light gray bands are $90 \%$ confidence bands. 
downward trend for 3-4 quarters and reach -6 basis points. Then the average NIMs reach normal in 8 quarters.

The possible explanations for these results point to the fact that banks in highest decile are constrained by regulatory capital requirements. As a positive TFP shock hits the economy, they cannot adjust the loan portfolio immediately. Although interest earned jumps by 4 basis points immediately because the capital is now more productive, the interest expense jumps by 6 basis points because investors now demand more return for holding the capital. This results in a negative jump in NIM. This essentially means that capital constrained banks sees a negative growth in profits when a positive TFP shocks appear. This will result in further worsening loan portfolio. Hence for the highest decile, positive TFP shock results in negative growth in loan portfolio. Whereas other banks with enough slack in capital requirements would be able to immediately capitalize on improving economy.

The interest paid on liabilities seem to be determined by movements in short rates which bank sizes cannot influence directly. Thus the impulse responses show no distinct pattern across sizes. However, the differential between interest earned on loans show that smaller banks are able to issue higher return loans when the economy improves.

These results have interesting implications for the macroeconomic prevalence for an accelerator mechanism and policy recommendation for a higher capital requirements.

Firstly, the accelerator mechanism seem to work justifiably well in aggregate data. However, it would require unconstrained banks which are able to adjust their portfolio in response to productivity shocks. Bernanke et al. (1999) assumes banks can arbitrarily adjust their loan portfolios and that seems to be perfect situation for the accelerator mechanism to work. 
The policy recommendation in the wake of financial crises of 2007-2012 was a call for increase in minimum capital requirements. There seem to be an unexplored side of the recommendation. As banks become more constrained, they would be slower to adjust to the economy. The best situation seems to have a higher capital requirement recommendations but a lower absolute bound to declare failure. There needs to be more empirical and theoretical study to understand these implications.

\section{Conclusion}

This paper points out a gap in the common macroeconomic understanding that bank's amplify shock due to balance sheet constraint put by capital regulation. Banks are assumed to lever up to the profit-maximizing level of capital choice that trades off risk and reward. However our empirical analysis show that for every dollar increase in profit, banks increase their loan portfolio less than a dollar and do not immediately adjust the deposit issuance dollar for dollar to lever up to the current leverage ratio. The coefficients for loan growth and deposit growth are generally increasing in size deciles. Thus largest banks are more tightly constrained and all other banks maintain discretionary capital in excess of regulatory requirements.

I show that in cross-section across bank sizes, banks of different sizes differ systemically in various capital structure parameters. The larger banks maintain significantly lower equity, use higher leverage, higher average loan to asset and issue more non-deposit liabilities. Whereas, the bank in largest deciles have significantly higher average net interest income and average net interest margin.

I believe that the future macroeconomic literature needs to account for the role of bank size in determining the role of bank capital structure in propagation and amplification of TFP shocks. While it seems true that banks propagate and amplify 
TFP shocks, it seems to happen differently for banks of different sizes. It is possible to improve the infinite-horizon DSGE models by incorporating banks that maintain discretionary capital and thus the capital constraint does not bind. 


\section{Bibliography}

Viral V Acharya and Nada Mora. Are banks passive liquidity backstops? deposit rates and flows during the 2007-2009 crisis. Technical report, National Bureau of Economic Research, 2012.

Viral V Acharya, Joao Santos, Tanju Yorulmazer, et al. Systemic risk and deposit insurance premiums. Citeseer, 2010.

Anat Admati and Martin Hellwig. The Bankers' New Clothes: What's Wrong with Banking and What to Do about It-Updated Edition. Princeton University Press, 2014.

Anat R Admati, Peter M DeMarzo, Martin F Hellwig, and Paul Pfleiderer. The leverage ratchet effect. The Journal of Finance, 73(1):145-198, 2018.

Roger Aliaga-Díaz and María Pía Olivero. Is there a financial accelerator in us banking?: Evidence from the cyclicality of banks' price-cost margins. Economics Letters, 108(2):167-171, 2010.

Yener Altunbaş, Caterina Di Tommaso, and John Thornton. Is there a financial accelerator in european banking? Finance Research Letters, 17:218-221, 2016.

Ben Bernanke, Mark Gertler, and Simon Gilchrist. The financial accelerator and the flight to quality. Technical report, National Bureau of Economic Research, 1994.

Ben S Bernanke, Mark Gertler, and Simon Gilchrist. The financial accelerator in a quantitative business cycle framework. Handbook of macroeconomics, 1:1341-1393, 1999.

Charles T Carlstrom and Timothy S Fuerst. Agency costs, net worth, and business fluctuations: A computable general equilibrium analysis. The American Economic Review, pages 893-910, 1997. 
Eduardo Davila and Ansgar Walther. Does size matter? bailouts with large and small banks. Technical report, National Bureau of Economic Research, 2017.

Harry DeAngelo and René M Stulz. Liquid-claim production, risk management, and bank capital structure: Why high leverage is optimal for banks. Journal of Financial Economics, 116(2):219-236, 2015.

Douglas W Diamond and Philip H Dybvig. Bank runs, deposit insurance, and liquidity. Journal of political economy, 91(3):401-419, 1983.

Douglas W Diamond and Raghuram G Rajan. A theory of bank capital. The Journal of Finance, 55(6):2431-2465, 2000.

Itamar Drechsler, Alexi Savov, and Philipp Schnabl. The deposits channel of monetary policy. The Quarterly Journal of Economics, 132(4):1819-1876, 2017.

Steven Fazzari, R Glenn Hubbard, and Bruce Petersen. Investment, financing decisions, and tax policy. The American Economic Review, 78(2):200-205, 1988.

John Fernald. A quarterly, utilization-adjusted series on total factor productivity. Federal Reserve Bank of San Francisco, 2014.

Neville Francis, Michael T Owyang, Jennifer E Roush, and Riccardo DiCecio. A flexible finite-horizon alternative to long-run restrictions with an application to technology shocks. Review of Economics and Statistics, 96(4):638-647, 2014.

Leonardo Gambacorta and Hyun Song Shin. Why bank capital matters for monetary policy. Journal of Financial Intermediation, 35:17-29, 2018.

Mark Gertler and Peter Karadi. A model of unconventional monetary policy. Journal of monetary Economics, 58(1):17-34, 2011.

Mark Gertler and Peter Karadi. Monetary policy surprises, credit costs, and economic activity. American Economic Journal: Macroeconomics, 7(1):44-76, 2015.

Mark Gertler and Nobuhiro Kiyotaki. Financial intermediation and credit policy in business cycle analysis. In Handbook of monetary economics, volume 3, pages 547-599. Elsevier, 2010.

Mark Gertler and Nobuhiro Kiyotaki. Banking, liquidity, and bank runs in an infinite horizon economy. American Economic Review, 105(7):2011-43, 2015. 
Mark Gertler, Peter Karadi, et al. Qe 1 vs. 2 vs. $3 \ldots$ : A framework for analyzing large-scale asset purchases as a monetary policy tool. international Journal of central Banking, 9(1):5-53, 2013.

Mark Gertler, Nobuhiro Kiyotaki, and Andrea Prestipino. Wholesale banking and bank runs in macroeconomic modeling of financial crises. In Handbook of Macroeconomics, volume 2, pages 1345-1425. Elsevier, 2016.

Marvin Goodfriend and Bennett T McCallum. Banking and interest rates in monetary policy analysis: A quantitative exploration. Journal of Monetary Economics, 54(5):1480-1507, 2007.

Reint Gropp and Florian Heider. The determinants of bank capital structure. Review of finance, 14(4):587-622, 2010.

Samuel G Hanson, Andrei Shleifer, Jeremy C Stein, and Robert W Vishny. Banks as patient fixed-income investors. Journal of Financial Economics, 117(3):449-469, 2015.

Oliver Hart and John Moore. A theory of debt based on the inalienability of human capital. The Quarterly Journal of Economics, 109(4):841-879, 1994.

Oliver Hart and Luigi Zingales. Liquidity and inefficient investment. Journal of the European Economic Association, 13(5):737-769, 2015.

Òscar Jordà. Estimation and inference of impulse responses by local projections. American economic review, 95(1):161-182, 2005.

Alejandro Justiniano, Giorgio E Primiceri, and Andrea Tambalotti. Investment shocks and the relative price of investment. Review of Economic Dynamics, 14 (1):102-121, 2011.

Nobuhiro Kiyotaki and John Moore. Credit cycles. Journal of political economy, 105 (2):211-248, 1997.

Valerie A Ramey. Macroeconomic shocks and their propagation. In Handbook of Macroeconomics, volume 2, pages 71-162. Elsevier, 2016.

Robert M Townsend. Optimal contracts and competitive markets with costly state verification. Journal of Economic theory, 21(2):265-293, 1979. 